\title{
Bir Vakıf Üniversitesi Sağlık Hizmetleri Meslek Yüksekokulunda Öğrenim Gören Öğrencilerin Genel Afete Hazırlıklı Olma İnanç Durumlarının Belirlenmesi
}

\author{
Bekir ERTUĞRUL ${ }^{1}$, Servi Damla ÜNAL ${ }^{2}$
}

\begin{abstract}
Özet
Araştırma bir vakıf üniversitesi öğrencilerinin genel afete hazırlık inancını belirlemek amacıyla yapılmıştır. Tanımlayıcı tipte yapılan araştırma Ankara ilinde bir vakıf üniversitesi sağlı hizmetleri meslek yüksekokulu öğrencileriyle 20-30 Mayıs 2019 tarihleri arasında yapılmıștır. Araștırmanın evrenini yüksekokulda öğrenim gören toplam 748 öğrenci oluştururken, örneklem seçimine gidilmemiş olup araştırmanın yapıldığı tarihlerde okulda bulunan ve araştırmaya katılmayı kabul eden 400(evrenin \%53'ü) öğrenci ile araştırma tamamlanmıştır. Veri toplama araçları, öğrencilerin tanımlayıcı özellikleri ve genel afete hazırlık inancını etkileyen faktörleri belirlemek için kullanılan anket formu ve genel afete hazırlık inanç ölçeğidir (cronbach alpha: 0.81). Verilerin istatistiksel analizinde sayı, ortalama, yüzde, standart sapma, kolmogorov smirnov normallik testi, bağımsız örneklem $t$ ve one-way ANOVA testi kullanılmıștır. Araştırmanın yapılması için gerekli izinler ve etik onay alınmıştır. Araştırma öz bildirime dayalıdır. Katılımcılardan yazılı onam alınmıștır.
\end{abstract}

Öğrencilerin \%74'ünün kadın olduğu, \%88.8'inin 17-22 yaş grubunda ve \%34.5'inin İlk ve Acil Yardım bölümünde olduğu tespit edilmiștir. Öğrencilerin genel afete hazırlık inanç ölçeği toplam puan ortalaması $111.57 \pm 12.36$ olarak tespit edilmiştir. Öğrencilerin genel afete hazırlık inanç ölçeği toplam puan ortalaması ile daha önce afetlerle ilgili eğitim alma, okulda acil durum/afet planı hakkında bilgi sahibi olma, acil durum/afetlere hazırlıklı olma ve okulda acil durum/afet durumunda toplanma noktasını bilme durumları arasında istatistiksel olarak anlamlı bir fark olduğu belirlenmiştir $(\mathrm{p}<0.05)$.

Öğrencilerin genel afete hazırlıklı olma inanç düzeyi puanının ortalamanın üzerinde olduğu ve kız öğrencilerin erkek öğrencilerden daha yüksek olduğu görülmüștür. Afetlerle ilgili eğitim alan öğrencilerin afete hazırlıklı olma inancının afet eğitimi almayanlara göre daha yüksek olduğu belirlenmiştir. Bu açıdan üniversitelerde acil durum ve afet yönetimi ile ilgili bilgilendirici ve bilinçlendirici eğitim programlarının düzenlenmesi, ders müfredatına konulması, görsel afişlerin, simülatörlerin kullanılması ve afete hazırlık amaçlı tatbikatların yapılması önerilmektedir.

Anahtar Kelimeler: Afet, Afete Hazırlık İnancı, Sağlık İnanç Modeli

\footnotetext{
${ }_{1}$ Ögr. Gör., Başkent Üniversitesi, Sağlık Hizmetleri MYO, İlk ve Acil Yardım Prog. Ankara

İlgili yazar e-posta/ Corresponding author e-mail: bertugrul@baskent.edu.tr Orcid No: 0000-0003-2787-0869

2 Başkent Üniversitesi, Sağlık Hizmetleri MYO, İlk ve Acil Yardım Prog., Ankara

e-posta/e-mail: sdamlaunal@gmail.com Orcid No: 0000-0001-6205-5996
}

Bu makaleye atıf yapmak için- To cite this article Ertuğrul, B. ve Ünal. S. D. (2020). Bir Vakıf Üniversitesi Sağllk Hizmetleri Meslek Yüksekokulunda Öğrenim Gören Öğrencilerin Genel Afete Hazırlıklı Olma İnanç Durumlarının Belirlenmesi. Afet ve Risk Dergisi, 3(1), 31 - 45. 


\title{
Determination of General Disaster Preparedness Beliefs of Students Studying at a Foundation University Health Services Vocational School
}

\begin{abstract}
The research was carried out to determine the general disaster preparedness belief of university students. The descriptive study was conducted with students from a foundation university health services vocational school in Ankara, between 20-30 May 2019. While the total population of the study was 748 students studying at the college, no sample selection was made and the study was comleted with 400 students $53 \%$ of the universe) who were in the school at the time of the study and agreed to participate in the research. The data collection tools are the questionnaire form and the general disaster preparedness faith scale (cronbach alpha: 0.81) used to determine the descriptive characteristics of students and the factors affecting their general disaster preparedness belief. In statistical analysis of data, number, mean, percentage, standard deviation, kolmogorov smirnov normality test, independent sample t test and one-way ANOVA test were used. Necessary permissions and ethical approval were obtained to conduct the research. The researchis based on self-report. Written consent was obtained from the participants.
\end{abstract}

It was determined that $74 \%$ of the students were women, $88.8 \%$ were in the $17-22$ age group and $34.5 \%$ were in the First and Emergency Aid section. Total disaster preparedness belief scale of the students was determined as $111.57 \pm 12.36$. A statistically significant difference between students' overall disaster preparednessbelief scale total score average and prior education about disasters, having knowledge about emergency/disaster plan at school, being prepared for emergency/disasters, and knowing the point of meeting in case of emergency/disaster at school there was a difference $(p<0.05)$.

It was observed that the students' general disaster preparedness belief level score was above average and female students were higher than male students. It has been determined that the belief that students who are trained in disaster preparedness for disaster is higher than those who do not receive disaster education. In this respect, it is recommended to organize informative and awareness-raising training programs about emergency and disaster management in universities, to put them in the curriculum, to use visual posters, simulators and to prepare for disaster prepared exercises.

Keywords: Disaster, Disaster Preparedness Belief, Health Belief Model

\section{GİRIŞ}

İnsanlık tarihi var olduğu günden bugüne kadar yaşadığı çevreyi anlamaya çalışmaktadır. İnsan doğadan doğa ise insandan etkilenmektedir. Bazen bu etkileşim olayları yaşanılan çevre üzerinde yıkıcı etkiler bırakmakta, kendine özgü can ve mal kaybına neden olmaktadır (Şahin ve Üçgül, 2019). Afet, toplumun tamamı veya belli kesimleri için fiziksel, ekonomik ve sosyal kayıplar doğuran, normal hayatı ve insan faaliyetlerini durduran veya kesintiye uğratan, etkilenen toplumun baş etme kapasitesinin yeterli olmadığı doğa, teknoloji veya insan kaynaklı olaydır (AFAD, 2019c).

Afetler tür olarak doğal ve insan kaynaklı(teknolojik) olmak üzere iki grupta toplanmaktadır (Yıldırım, 2004). Deprem, sel, orman tahribatları, ekolojik kirlenme, volkanik patlamalar, tsunami, kuraklık ve veba salgınları doğal afetler içerisinde yer alırken, kimyasal ve endüstriyel kazalar, 
nükleer kazalar, uçak kazaları, terörizm, demiryolu ve gemi kazaları teknolojik afetler içerisinde yer almaktadır. Teknolojik afetler insanlar tarafından oluşturulabileceği gibi doğal afetler sonucu da meydana gelebilmektedir (Kadığlu, 2008).

Dünya genelinde olduğu gibi Türkiye'de de afetlerin çoğu meteorolojik kaynaklıdır. Meteoroloji Genel Müdürlüğü'nün (MGM) 2017 yılı verilerine göre, Türkiye'de meydana gelen iklimsel afetlerin \%36'sı fırtına ve hortum, \%31'i şiddetli yağışlar ve yağışların neden olduğu sel baskınları, \%16'sı dolu, \%7'si kar, \%4'ü yıldırım ve geriye kalan 6'sı ise diğer nedenlerden (çı̆̆, don, orman yangınları, sis, kuraklık ve yüksek sıcaklık) oluşmaktadır (URL-1, Şekil 1a). MGM'nin 2018 yılı verilerine göre ise Türkiye'de meydana gelen iklimsel afetlerin \%38'ini şiddetli yağış/sel, \%28'sini fırtına, \%17'sini ise dolu, \%6'sı kar, \%5'i yıldırım ve \%6'sı diğer nedenlerden (don, heyelan, çı̆̆, orman yangını) kaynaklı olduğu tespit edilmiştir (URL-2, Şekil 1b).

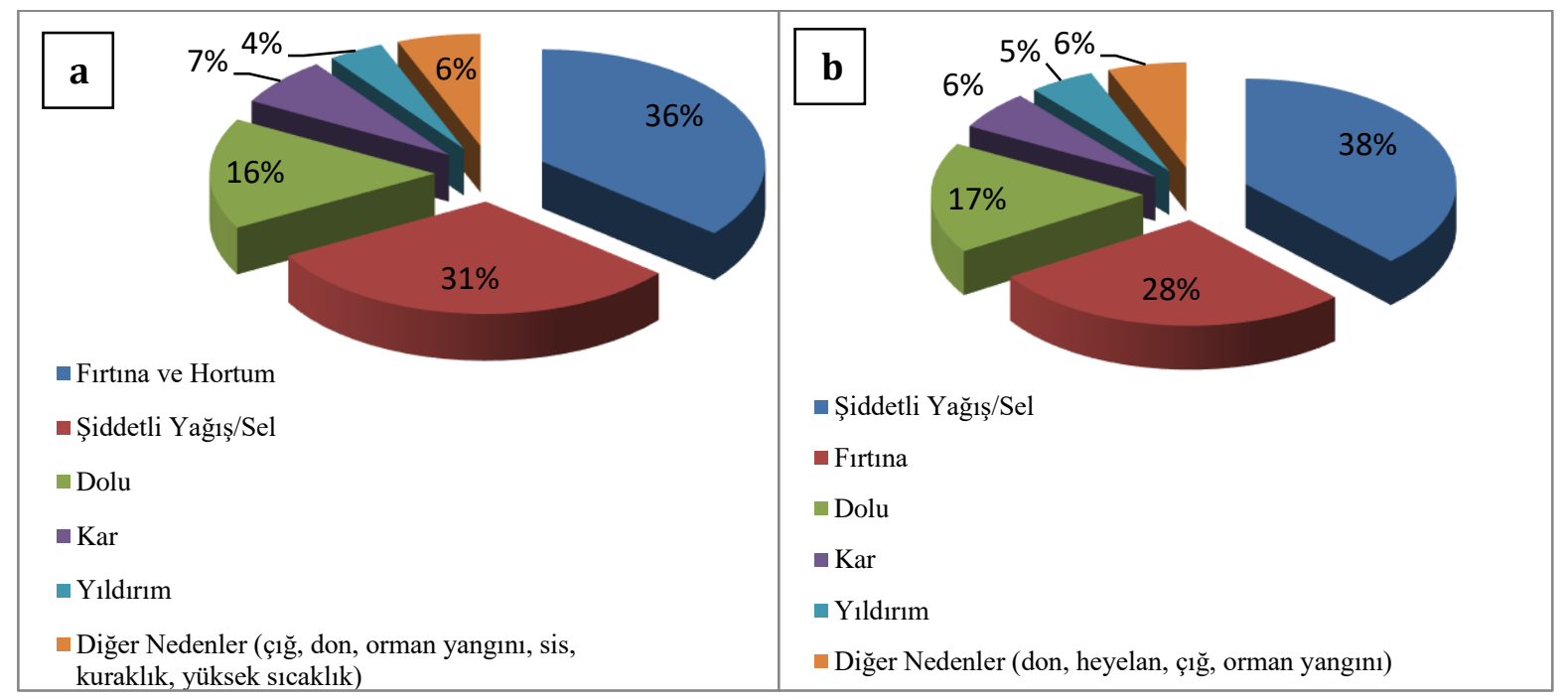

Şekil 1. MGM'nin verilerine göre olağanüstü olayların oransal dağılımı a) 2017 yılı (URL-1), b) 2018 yılı

(URL-2)

Afetlerin zararlarının azaltılmasına yönelik dünyada ilk eylem planı 1994 yılında "Yokohama Strateji Belgesi" ismiyle bilinmektedir. Bu belgede afet risklerinin tespit edilmesi, küresel ve bölgesel risklerin bertaraf edilmesi için uygulama esasları, öncelikler ve tanımlamalar yapılmıştır. 2003 yılında Birleşmiş Milletler Genel Kurulu'nda temeli Yokohama Strateji Belgesi olan "Hyogo Eylem Çerçevesi" kabul edilmiştir. 2005-2015 yıllarını kapsayan bu eylem planının hedefleri ise üç ana başlıkta toplanacak olursa bunlar; afet riskinin önlenmesi, sivil toplum kuruluşlarının geliştirilmesi ve afetlerden zarar gören toplumların acil durum hazırlığını içermektedir. 2015 yılında ise daha uzun süre kullanılabilecek ve daha geniş kapsamlı Sendai Bildirgesi kabul edilmiş olup 2015-2030 yılları arasını kapsamaktadır. Bu bildirgede genel olarak bakıldığında 4 öncelik belirlenmiş olup bunlar; afet risklerinin belirlenmesi, afet riskleri ile mücadele edebilmek için yönetimin güçlenmesi, afetlerde erken dönemde iyileşme için afet riskini azaltmaya yönelik yatırımlar ve etkin müdahale, yapılanma, kurtarma faaliyetlerini iyi hale getirmek için afetlere hazırlık çalışmalarının iyileştirilmesi sayılabilir (Macit, 2019).

Afetler, bölgesel olarak farklılık göstermektedir. 2012 yılında ilk kez yapılan risk yönetimi endeksine (INFORM) göre 191 ülke modellenmiştir. Amacl; afetlerin riskini ve insani krizleri ölçerek sıralamaktır. Endeks puanı 0 ile 2 arasında olanlar riski çok düşük, 2 ile 3.5 arasında olanlar düşük, 3.5 ile 5 arasında olanlar orta, 5 ile 6.5 arasında olanlar yüksek ve 6.5 ile 10 arasında olanlar ise çok yüksek risk olarak değerlendirilmektedir. Türkiye'nin endeks puanı 5.0 olarak belirlenmiş olup 191 ülke arasında 45. sırada yer almaktadır. Türkiye'nin komşuların $\neg$ dan 
Bir Vakıf Üniversitesi Sağlık Hizmetleri Meslek Yüksekokulunda Öğrenim Gören Öğrencilerin Genel Afete Hazırlıklı Olma İnanç Durumlarının Belirlenmesi

Yunanistan 2.9, Bulgaristan 2.6, Suriye 6.9 Irak 6.8, İran 5.0, Azerbaycan 4.7 ve Gürcistan 3.8 puana sahiptir. Endeks puanı içinde yer alan alt bileșenlerin puan ve ülke bazında sıralamasına bakıldığında; tehlike ve maruziyet puanı 7.8, zarar görebilirlik puanı 6.0 ve baș etme kapasitesi eksikliği puanı ise 3.2 olarak belirlenmiștir. Buradan hareketle Türkiye tehlike ve maruziyet puanına göre 9. sırayı, zarar görebilirlik puanına göre 46. sırayı ve baş etme kapasitesi eksikliğinde ise 140. sırayı almıștır. Buna göre Türkiye değerlendirilecek olursa; tehlike ve maruz kalma açısından çok yüksek riskli, zarar görebilirlikte orta riskli ve baş etme kapasitesi açısından ise düşük riskli ülke olarak değerlendirilmektedir (AFAD, 2018).

Tehlike ve maruziyet riskinin çok yüksek olduğu ülkemizde bireylerin afete bakış açıları ve afete hazır olma durumları önem arz etmektedir. Afet meydana gelmeden önce yapılan afet riskini azaltma yönetimi çalışmalarının iyi olması felaket risklerini ve etkilerini azaltarak bu felaketler karşısında o toplumun hazırlıklı olmasını ve afet sonrasında da toparlanma kabiliyetini arttırmasını sağlamaktadır (Sari, 2019). Afet ve acil durum hazırlık çabaları ağırlıklı olarak insanların risk algılamasından afet olayları ve acil durumların doğrudan ve dolaylı geçmiş deneyimlerinden derslere kadar değişen çeşitli faktörlerden türetilen insan davranışlarına odaklanmaktadır (Ejeta, Ardalan ve Paton, 2015). Literatür taramalarında teoriler, davranışların yapısal ve psikolojik belirleyicilerini açıklamak ve sağlığın teşviki ve geliştirilmesi ve eğitiminin geliştirilmesine ve geliştirilmesine rehberlik etmek için kullanılabilir (Painter, Borba, Hynes, Mays ve Glanz, 2008).

Jeopolitik riskler göz önünde bulundurulduğunda afete hazırlıklı olmak gerekir. Afete hazırlıklı olmak riski, felaketi ve iyileşme düzeyini artırdığı gibi aynı zamanda da oluşabilecek maliyeti de en aza indirir. Örneğin yapısal (örn. savunulabilir bir alan yaratma, binaların ve yer sarsıntısının etkisine karşı koymak için içeriğin güvence altına alınması) ve hayatta kalma (örneğin, yiyecek, su, pișirme kaynaklarının depolanması vb.) gibi hazırlık tedbirleri yaralanma ve ölüm riskini azaltır (Paton,2018).

Birleșmiș Milletler Uluslararası Afet Riski Azaltma Stratejisi, hazırlıklı olma durumunu hükümetler, müdahale ve iyileştirmeler, topluluklar ve bireyler tarafından olası, yakın veya güncel afetlerin etkilerini geliştirmek, müdahale etmek ve bunlardan kurtulmak için geliștirilen bilgi ve kapasiteler olarak tanımlar (UNISDR, 2016). Bu tanımın önemli bir bileșeni, geliştirilecek bilgi ve kabiliyet ihtiyacını ifade etmesidir.

Türkiye'de afetlere hazırlık kapsamında 2009 yılında afet yönetim modeli uygulamasına geçilmiş olup daha önce kriz yönetimi olan modelden risk yönetimi modeline geçilmiștir. Günümüzde bu model bütünleşik afet yönetimi sistemi olarak kabul edilmektedir. Bu model ise acil durum ve afetin neden olduğu tehlike ve maruziyetin önceden tespit edilmesi, afet meydana gelmeden önce zararları önlemek ve azaltmak için önlemlerin alınması, etkili müdahale, koordinasyon ve afet meydana geldiğinde de toparlanma sürecinin yürütülmesini sağlamaktır. Buna yönelik 2009 yılında Türkiye Acil Durum Yönetimi Genel Müdürlüğü kapatılarak Başbakanlık’a bağlı Afet ve Acil Durum Yönetimi Başkanlığı (AFAD) kurulmuş olup 15 Temmuz 2018 yılında İçişleri Bakanlığı'na bağlanmıştır (AFAD, 2019a).

AFAD'ın 2014 yılında yaptığı bir araştırmada katılımcılara afetlere ne kadar hazırlıklı oldukları sorulduğunda kesinlikle hazırlıksız olanlar ve hazırlıksız olanlar toplamı tüm katılımcıların \% 69.7'sini oluşturmaktadır. Yine aynı araştırmada afete hazırlıklı yaşamanın ne kadar önemli olduğu sorulduğunda önemli ve kesinlikle önemli cevabı verenlerin oranı tüm katılımcıların \% 94.7'sini oluşturmaktadır (AFAD, 2014). 
Afet risklerinin azaltılması ve afete yönelik stratejilerin geliştirilmesi için AFAD afete hazır aile, afete hazır okul, afete hazır işyeri ve afete hazır gençler eğitimleri ile afete Hazır Türkiye projesini yürütmektedir. Okullarda Afet ve Acil Durum Yönetimi projesi kapsamında risk ve tehlike analizi, okul ve aile planlaması, ortaya çıkacak zararları azaltma, güvenli ve sağlam okul binaları, operasyon prosedürleri, tatbikatlar ve öğrenci teslim prosedürleri faaliyetleri bulunmaktadır (AFAD, 2019b). Benzer şekilde ilgili birimler tarafından müfredat programlarının oluşturulması afetlerin sebep olacağı olumsuz sonuçların azaltılmasını sağlayacaktır. Araştırmalar öğrencilerin afet eğitimiyle ilgili programlara katılmasının olumlu etkisi olacağından bahsetmektedir (Ersoy vd., 2017).

Eğitim açısından bakıldığında ülkemizde afetten korunma kültürü ve farkındalığı yeterli olmamakla birlikte ilk ve ortaöğretimde verilirken yükseköğrenimde verilmemektedir. Üniversitelerde Acil Yardım ve Afet Yönetimi Bölümü az sayıda mevcuttur. Afete hazır olmak için eğitim ile bireyden başlanarak topluma ulaşılmalıdır (Varol \& Kırıkkaya, 2017). Tüm bunlardan hareketle bu araştırma Sağlık Hizmetleri Meslek Yüksekokulu öğrencilerinin teorik bir çerçeve olarak Sağlık İnanç Modeli'ne dayalı Genel Afete Hazırlıklı olma İnancı ile sosyodemografik ve acil durumla/afetle ilgili faktörlerin ilişkisini tespit etmek amacıyla yapılmıştır

\section{GEREÇ ve YÖNTEM}

Tanımlayıcı tipte yapılan bu araștırma, Başkent Üniversitesi Sağllk Hizmetleri Meslek Yüksekokulu'nda 20-30 Mayıs 2019 tarihleri arasında yapılmıştır. Araștırmanın evrenini 10 bölüm bulunan Sağlık Hizmetleri Meslek Yüksekokulu'nda öğrenim gören (ilk ve acil yardım, anestezi, patoloji, iş sağlığı ve güvenliği, fizyoterapi, tıbbi dokümantasyon ve sekreterlik, ameliyathane hizmetleri, ağız ve diş sağlığı, diyaliz, tıbbi görüntüleme teknikleri) 748 öğrenci oluşturmuştur. Araştırmada örneklem seçimine gidilmemiş olup araştırmanın yapıldığı tarihlerde okulda bulunan ve araştırmaya katılmayı kabul eden 400 (\%53) ön lisans öğrencisi araştırmanın örneklemini oluşturmuştur.

Araştırmanın veri toplama araçları 2 bölümden oluşmaktadır. 1. bölüm katılımcıların sosyodemografik özellikleri ve acil duruma/afete hazırlık durum değişkenleri; yaş, cinsiyet, sınıf, bölüm, medeni durum, gelir durumu, sosyal güvence ve bugüne kadar en uzun yaşanan yer, daha önce afet yaşama durumu, afet eğitimi alma durumu, okulda afet/acil durum hazırlık planı bilgi durumu, acil durum/afetlere hazırlık durumu, evde acil durum/afet çantası olma durumu ve okulda acil durum/afet durumunda toplanma noktasını bilme durumu gibi bağımsız değişkenleri içermektedir. 2. bölüm ise araştırmanın bağımlı değişkeni olan genel afete hazırlık inanç ölçeğinden oluşmaktadır.

Genel afete hazırlık inanç ölçeği 2018 yılında Ebru İnal, Nuri Doğan ve Kerim Hakan Altıntaş tarafından geliştirilmiștir (Inal et al., 2018). Sağlık İnanç Modeli'ne dayalı ölçek genel afete hazırlık inancını ölçmektedir. 31 maddeden oluşan ölçeğin 6 alt boyutu bulunmaktadır. Bunlar; algılanan duyarlılık ( 6 madde), algılanan engeller ( 6 madde), algılanan yarar ( 3 madde), algılanan ciddiyet (3 madde), öz yeterlilik ( 8 madde) ve eyleme geçiricilerdir (5 madde). Alt boyutlar; Sağlık İnanç Modeli'nde yer alan boyutların afetlere yönelik değerlendirmesini sağlar. Sağlık İnanç Modeli alt boyutları şunları ölçmektedir:

Algılanan Duyarlılık; bireyin herhangi bir hastalığa yakalanma ya da sağlıkla ilgili bir etkiye maruz kalma olasılığı konusundaki inancıdır.

Algılanan Ciddiyet; sağlık problemini algılama konusundaki ciddiyettir. 
Bir Vakıf Üniversitesi Sağlık Hizmetleri Meslek Yüksekokulunda Öğrenim Gören Öğrencilerin Genel Afete Hazırlıklı Olma İnanç Durumlarının Belirlenmesi

Algılanan Yarar; bir kişinin davranış değişikliğini ne kadar faydalı algıladığı, eğer o davranış değişikliğini gerçekleştirirse hastalık riskini önleyebileceğine ne kadar inandığıdır.

Algılanan Engeller; önerilen davranıșı gerçekleștirmenin önünde algılanan somut ya da duygusal engeller ya da bu davranıșın yol açacağı düşünülen istenmeyen sonuçlardır.

Eyleme Geçiriciler; sağlık davranışının ortaya çıkma insidansına etki etmektedir. Eyleme geçiriciler içsel (internal) ya da dışsal (external) olabilmektedir. İçsel eyleme geçiriciler hastalığa özgü rahatsızlık belirtilerinin hissedilmesidir. Dışsal eyleme geçiriciler ise medya kitlesi, öğütler, posterler, 'bilboard'lar, gazete ve magazin makaleleri ile sağlık profesyonelleri tarafindan hazırlanan hatırlatıcılardır.

Öz-Yeterlilik; bireyin istenilen sonuca ulaşmak için gereken eylemleri yapabilme yeteneğine olan inançlarıyla ilgilidir.

Ölçeğin kesme noktası bulunmamaktadır. Ölçeğin iç güvenirlik katsayısı olan cronbach alpha $(\alpha)$ değeri 0.93 olarak tespit edilmiştir. Alt boyutların cronbach alpha $(\alpha)$ değerleri; öz yeterlilik alt boyutu 0.90, eyleme geçiriciler alt boyutu 0.84 , algılanan duyarlılık alt boyutu 0.76, algılanan engeller alt boyutu 0.75 , algllanan yararlar alt boyutu 0.80 ve algllanan ciddiyet alt boyutu ise 0.74 olarak tespit edilmiștir. Araștırmada ölçeğin cronbach alpha $(\alpha)$ değeri 0.81 olarak bulunmuştur. Ölçeğin puanlama sistemi olumlu ifadeler için (1) Kesinlikle katılmıyorum, (2) Katılmıyorum, (3) Kararsızım, (4) Katılıyorum, (5) Kesinlikle katılıyorum șeklinde yapılırken, olumsuz ifadeler için; (5) Kesinlikle katılmıyorum, (4) Katılmıyorum, (3) Kararsızım, (2) Katılıyorum, (1) Kesinlikle katılıyorum şeklinde ters kodlama yapılmıştır. Ölçekten minimum 31 puan, maksimum ise 155 puan alınmaktadır. Alt boyutların puanlama sistemi ise; öz yeterlilik alt boyutu en düşük 8 puan en yüksek 40 puan, eyleme geçiriciler alt boyutu en düşük 5 puan en yüksek 25 puan, algılanan duyarlılık alt boyutu en düşük 6 puan en yüksek 30 puan, algllanan engeller alt boyutu en düşük 6 puan en yüksek 30 puan, algılanan yarar en düșük 3 puan en yüksek 15 puan ve algılanan ciddiyet alt boyutu en düşük 3 puan en yüksek 15 puan şeklindedir. Toplam ölçek puan ortalaması $102.3 \pm 15.3$ olarak bulunmuş olup araștırmanın bağımlı değişkenidir. Araştırmanın verileri anket uygulaması yöntemiyle toplanmıştır.

Araştırmanın yapılabilmesi için Başkent Üniversitesi Sosyal ve Beșeri Bilimler Bilimsel Araştırma ve Yayın Etiği Kurulu'ndan (Tarih:16.05.2019, Karar sayı: 17162298.600-252) yazılı izin alınmıștır. Ölçek kullanım izni için ölçeği geliștiren araștırmacılardan olan Ebru İnal'dan mail yoluyla izin alınmıștır. Araștırmayı kabul eden öğrencilerden "Bilgilendirilmiș Onam İlkesi", “Gönüllülük İlkesi” ve "Gizlilik İlkesi” yerine getirilerek sözlü ve yazılı onam alınmıștır.

Araștırmanın verilerinin analizinde SPSS 22.0 paket programı kullanılmıștır. Verilerin analizinde ortalama, yüzdelik, standart sapma, kolmogorov smirnov normallik testi uygulanmıștır. Kolmogorov smirnov normallik testi sonucu verilerin normal dağılım verdiği tespit edilmiștir. Bunun üzerine sosyo-demografik özellikler ve acil durumla/afetle ilgili bağımsız değişkenlerin genel afete hazırlık inanç ölçeği toplam puan ortalamasına etkisini belirlemek için bağımsız örneklem $t$ testi ve one-way ANOVA testi uygulanmıştır.

Araştırma Başkent Üniversitesi Sağlık Hizmetleri Meslek Yüksekokulu'nda öğrenim gören öğrencileri kapsadığından tüm öğrencilere genellenemez. Ayrıca veri toplama sırasında okulda bulunan gönüllü öğrencilerle yapılması bu araștırmanın sınırlılı̆̆ını oluşturmaktadır. 


\section{BULGULAR}

Başkent Üniversitesi Sağlık Hizmetleri Meslek Yüksekokulu öğrencilerinin bağımsız değișken (yaș, cinsiyet, bölümü, daha önce afet yaşama durumu, daha önce afetlerle ilgili eğitim alma durumu, okulda acil durum/afet hazırlık planı hakkında bilgi durumu, acil durum/afetlere hazırlıklı olma durumu, evlerinde acil durum/afet çantası olma durumu, okulda acil durum/ afet durumunda toplanma yerini bilme durumu) dağılımları tablolar halinde verilmiştir.

Öğrencilerin kişisel durum değişkenlerine ilişkin bulgular incelendiğinde; öğrencilerin en az 17, en fazla 58 yaşında olduğu görülmektedir. Yaş ortalaması $20.66 \pm 2.912$ olarak belirlenmiştir. Öğrencilerin \%88.8'inin 17-22 yaş grubunda, \%74'ünün kadın olduğu, \%34.5'inin İlk ve Acil Yardım bölümünde olduğu tespit edilmiştir. Öğrencilerin \%62.7'sinin 1. sınıf, \%37.3'ünün 2. sınıf olduğu, \%71.8'inin gelirinin giderine eşit olduğu, \%66.0'sının hayatlarının büyük bölümünü büyükşehirde geçirdiği belirlenmiştir (Tablo 1).

Tablo 1. Araştırmaya Katılan Öğrencilerin Kişisel Durum Değişkenlerinin Dağılımı (n=400)

\begin{tabular}{|c|c|c|c|}
\hline & & $\mathbf{n}$ & $\%$ \\
\hline \multirow{3}{*}{ Yaş Grupları } & 17-22 yaş arası & 355 & 88.8 \\
\hline & 23-28 yaş arası & 37 & 9.3 \\
\hline & 29 yaş ve üstü & 8 & 2.0 \\
\hline Alt Sinır= 17 & Üst Sınır= 58 & $\begin{array}{r}\text { Ortalama= } \\
20.66\end{array}$ & $\mathrm{SS}=2.912$ \\
\hline \multirow{10}{*}{ Bölüm } & İlk ve Acil Yardım & 138 & 34.5 \\
\hline & Anestezi & 26 & 6.5 \\
\hline & Tıbbi Görüntüleme Teknikleri & 37 & 9.3 \\
\hline & Ağız ve Diş Sağlığl & 26 & 6.5 \\
\hline & Patoloji & 41 & 10.3 \\
\hline & İş Sağlığı ve Güvenliği & 8 & 2.0 \\
\hline & $\begin{array}{l}\text { Tıbbi Dökümentasyon ve } \\
\text { Sekreterlik }\end{array}$ & 26 & 6.5 \\
\hline & Fizyoterapi & 36 & 9.0 \\
\hline & Ameliyathane Hizmetleri & 20 & 5.0 \\
\hline & Diyaliz & 42 & 10.5 \\
\hline \multirow{2}{*}{ Sinıf } & 1. Sinıf & 251 & 62.7 \\
\hline & 2. Sinıf & 149 & 37.3 \\
\hline \multirow{2}{*}{ Cinsiyet } & Erkek & 104 & 26.0 \\
\hline & Kadın & 296 & 74.0 \\
\hline \multirow{3}{*}{ Aile Gelir Durumu } & Gelir giderden az & 62 & 15.5 \\
\hline & Gelir gidere eşit & 287 & 71.8 \\
\hline & Gelir giderden fazla & 51 & 12.8 \\
\hline \multirow{3}{*}{$\begin{array}{l}\text { Bugüne Kadar En } \\
\text { Uzun Yaşanan Yer }\end{array}$} & Kent Merkezi & 116 & 29.0 \\
\hline & Köy/Kasaba & 20 & 5.0 \\
\hline & Büyükșehir & 264 & 66.0 \\
\hline
\end{tabular}

n: sayl; SS: standart sapma; \%: yüzdelik. 
Bir Vakıf Üniversitesi Sağlık Hizmetleri Meslek Yüksekokulunda Öğrenim Gören Öğrencilerin Genel Afete Hazırlıklı Olma İnanç Durumlarının Belirlenmesi

Öğrencilerin afete hazırlık durum değişkenlerine ilișkin özelliklerinin dağılımı incelendiğinde; öğrencilerin \%75.5'inin daha önce afet yaşamadığı, \%68.3'ünün daha önce afetlerle ilgili eğitim aldığı, \%65.3'ünün okulda acil durum/afet hazırlık planı hakkında bilgisi olmadığı, \%68.5'inin acil durum/afetlere yeterince hazırlıklı olmadığı, \%76.3'ünün evinde acil durum/afet çantası olmadığı ve $\% 72.5$ 'inin okulda acil durum/afet durumunda toplanma noktasının neresi olduğunu bilmediği tespit edilmiştir (Tablo 2).

Tablo 2. Araștırmaya Katılan Öğrencilerin Acil durumlara/Afetlere Hazırlık Durum Değişkenlerinin Dağılımı (n=400)

\begin{tabular}{|c|c|c|c|}
\hline & & $\mathbf{n}$ & $\%$ \\
\hline \multirow{2}{*}{ Daha önce afet yaşadınız mı? } & Evet & 98 & 24.5 \\
\hline & Hayır & 302 & 75.5 \\
\hline \multirow{2}{*}{ Daha önce afetlerle ilgili eğitim aldınız mı? } & Evet & 273 & 68.3 \\
\hline & Hayır & 127 & 31.8 \\
\hline \multirow{2}{*}{$\begin{array}{l}\text { Okulunuzda acil durum/afet hazırlık planı } \\
\text { hakkında bilginiz var mı? }\end{array}$} & Evet & 139 & 34.8 \\
\hline & Hayır & 261 & 65.3 \\
\hline \multirow{2}{*}{$\begin{array}{l}\text { Acil durum/afetlere yeterince hazırlıklı } \\
\text { mısınız? }\end{array}$} & Evet & 126 & 31.5 \\
\hline & Hayır & 274 & 68.5 \\
\hline \multirow{2}{*}{ Evinizde acil durum/afet çantanız var mı? } & Evet & 95 & 23.8 \\
\hline & Hayır & 305 & 76.3 \\
\hline \multirow{2}{*}{$\begin{array}{l}\text { Okulunuzda acil durum/afet durumunda } \\
\text { toplanma noktasının neresi olduğunu biliyor } \\
\text { musunuz? }\end{array}$} & Evet & 110 & 27.5 \\
\hline & Hayır & 290 & 72.5 \\
\hline
\end{tabular}

n: sayı; \%: yüzdelik

Öğrencilerin Genel Afete Hazırlık İnanç Ölçeği ve altı alt boyutundan aldıkları puan ortalamaları incelendiğinde; öğrencilerin öz yeterlilik alt boyut puan ortalaması $30.55 \pm 4.57$, eyleme geçiriciler alt boyut puan ortalaması $15.58 \pm 3.38$, algılanan duyarlılık alt boyut puan ortalaması $21.51 \pm 2.90$, algılanan engeller alt boyut puan ortalaması 19.92 \pm 4.07 , algllanan yarar alt boyut puan ortalaması $12.21 \pm 2.16$, algılanan ciddiyet alt boyut puan ortalaması $10.79 \pm 2.32$ ve genel afete hazırlık inanç ölçeği toplam puan ortalaması 111.57£12.36 olarak tespit edilmiştir (Tablo 3).

Tablo 3. Araştırmaya Katılan Öğrencilerin Genel Afete Hazırlık İnanç Ölçeği ve Alt Boyut Puanları (n=400)

\begin{tabular}{lccccc}
\hline & $\mathbf{n}$ & Min. & Max. & Ort. & SS. \\
\hline Öz Yeterlilik & 400 & 10.00 & 40.00 & 30.5500 & 4.57162 \\
\hline Eyleme Geçiriciler & 400 & 5.00 & 25.00 & 16.5850 & 3.38473 \\
\hline Algllanan Duyarlılık & 400 & 6.00 & 28.00 & 21.5100 & 2.90448 \\
\hline Algılanan Engeller & 400 & 6.00 & 30.00 & 19.9225 & 4.07960 \\
\hline Algllanan Yarar & 400 & 5.00 & 15.00 & 12.2150 & 2.16344 \\
\hline Algılanan Ciddiyet & 400 & 3.00 & 15.00 & 10.7900 & 2.32474 \\
\hline Toplam Ölçek Puanı & 400 & 80.00 & 146.00 & 111.5725 & 12.36008 \\
\hline m: sayı; Min: minimum; Max: maksimum
\end{tabular}

n: sayı; Min: minimum; Max: maksimum; Ort: ortalama; SS: standart sapma. 
Öğrencilerin kişisel durum değişkenleri ile toplam ölçek puan ortalamaları karşılaştırıldı̆̆ında; yaş grupları ve eğitim görülen bölüm ile genel afete hazırlık inanç ölçeği toplam puan ortalamaları arasında istatistiksel olarak anlamlı bir fark olmadığı tespit edilmiştir ( $p>0.05$ ) (Tablo 4).

Tablo 4. Kişisel Durum Değişkenleri ile Genel Afete Hazırlık İnanç Ölçeği Toplam Puan Ortalamasının Karşılaştırılması $(\mathrm{n}=400)$

\begin{tabular}{llrrrrr}
\hline & & $\mathbf{n}$ & $\overline{\mathbf{X}}$ & $\mathbf{S S}$ & $\mathbf{F}$ & $\mathbf{p}$ \\
\hline \multirow{3}{*}{ Yaş Grupları } & 17-22 yaş arası & 355 & 111.54 & 12.22 & & \\
& 23-28 yaş arası & 37 & 111.54 & 13.23 & 0.037 & 0.964 \\
& 29 yaş ve üstü & 8 & 112.75 & 15.70 & & \\
\hline \multirow{5}{*}{ Bölümm } & 138 & 112.61 & 12.62 & \\
& İlk ve Acil Yardım & 26 & 114.42 & 10.66 & \\
& Anestezi & 37 & 108.27 & 11.80 & \\
& Tibbi Görüntüleme Teknikleri & 26 & 109.46 & 13.60 & & \\
& Ağız ve Diş Sağlığı & 41 & 108.00 & 10.71 & & \\
& Patoloji & 8 & 109.87 & 11.98 & 1.155 & 0.323 \\
& İş Sağlı̆̆ı ve Güvenliği & & & \\
& Tıbbi Dokümantasyon ve & 26 & 112.65 & 10.66 & & \\
& Sekreterlik & 36 & 113.33 & 12.37 & & \\
& Fizyoterapi & 20 & 111.80 & 13.87 & & \\
& Ameliyathane Hizmetleri & 42 & 112.11 & 13.60 & & \\
& Diyaliz & & &
\end{tabular}

n: sayı; x̃: ortalama; SS: standart sapma; F: anova, p: anlamlı değer.

Öğrencilerin cinsiyeti ile toplam ölçek puan ortalamaları arasında istatistiksel olarak anlamlı bir ilişki vardır $(\mathrm{p}<0.05)$. Farkın kaynağı incelendiğinde kadınların genel afete hazırlık inancı puan ortalamasının erkeklere göre daha yüksek olduğu belirlenmiştir.

Öğrencilerin acil durum/afetlere hazırlık durum değişkenleri ile toplam ölçek puan ortalamaları karşılaştırıldığında; genel afete hazırlık inanç düzeyi ile öğrencilerin daha önce afet yaşama durumu arasında istatistiksel olarak anlamlı bir fark olmadığı tespit edilmiştir ( $p>0.05)$.

Öğrencilerin daha önce afetlerle ilgili eğitim alma durumu ile toplam ölçek puan ortalaması arasındaki farkın istatistiksel olarak anlamlı olduğu belirlenmiştir $(\mathrm{p}<0.05)$. Farkın kaynağı incelendiğinde daha önce afetlerle ilgili eğitim alan öğrencilerin genel afete hazırlık inanç ölçeği toplam puan ortalamasının almayanlara göre daha yüksek olduğu tespit edilmiştir.

Öğrencilerin okulda acil durum/afet planı hakkında bilgi durumu ile toplam ölçek puan ortalaması arasında istatistiksel olarak anlamlı bir ilișki vardır $(\mathrm{p}<0.05)$. Farkın kaynağı okulda acil durum/afet planı hakkında bilgisi olan öğrencilerin bilgisi olmayan öğrencilere oranla genel afete hazırlık inanç düzeyinin daha yüksek olmasından kaynaklanmaktadır.

Öğrencilerin acil durum/afetlere hazırlıklı olma durumu ile genel afete hazırlık inanç ölçeği toplam puan ortalaması arasında istatistiksel olarak anlamlı bir fark olduğu tespit edilmiştir $(\mathrm{p}<0.05)$. Farkın kaynağı incelendiğinde; acil durum/afetlere hazırlıklı olan öğrencilerin genel afete hazırlık inancı puan ortalamasının hazırlıklı olmayanlara göre daha yüksek olduğu belirlenmiştir.

Öğrencilerin evinde acil durum/afet çantası olması ile toplam ölçek puan ortalaması arasında istatistiksel olarak anlamlı bir ilişki vardır $(\mathrm{p}<0.05)$. Farkın kaynağı evinde acil durum/afet çantası 
Bir Vakıf Üniversitesi Sağlık Hizmetleri Meslek Yüksekokulunda Öğrenim Gören Öğrencilerin Genel Afete Hazırlıklı Olma İnanç Durumlarının Belirlenmesi

olan öğrencilerin genel afete hazırlık inancı puan ortalamasının olmayanlara göre daha yüksek olduğu belirlenmiştir.

Öğrencilerin okulda acil durum/afet durumunda toplanma noktasını bilme durumu ile toplam ölçek puan ortalaması arasında istatistiksel olarak anlamlı bir ilişki vardır $(\mathrm{p}<0.05)$. Farkın kaynağı incelendiğinde; okulda acil durum/afet durumunda toplanma noktasını bilen öğrencilerin genel afete hazırlık inancı puan ortalamasının bilmeyenlere göre daha yüksek olmasındandır (Tablo 5).

Tablo 5. Bazı Kişisel Durum ve Acil durumlara/Afetlere Hazırlık Durum Değişkenleri ile Genel Afete Hazırlık İnanç Ölçeği Toplam Puan Ortalamasının Karşılaştırılması (n=400)

\begin{tabular}{|c|c|c|c|c|c|c|c|}
\hline & & $\mathbf{n}$ & $\overline{\mathbf{X}}$ & SS & $\mathbf{t}$ & df & $\mathbf{p}$ \\
\hline \multirow{2}{*}{ Cinsiyet } & Erkek & 104 & 108.79 & 12.50 & \multirow{2}{*}{-2.682} & \multirow{2}{*}{398} & \multirow{2}{*}{$0.008^{*}$} \\
\hline & Kadın & 296 & 112.54 & 12.18 & & & \\
\hline \multirow{2}{*}{$\begin{array}{l}\text { Daha önce afet yaşama } \\
\text { durumu }\end{array}$} & Evet & 98 & 113.19 & 13.13 & \multirow{2}{*}{1.497} & \multirow{2}{*}{398} & \multirow{2}{*}{0.135} \\
\hline & Hayır & 302 & 111.04 & 12.07 & & & \\
\hline \multirow{2}{*}{$\begin{array}{l}\text { Daha önce afetlerle ilgili } \\
\text { eğitim alma durumu }\end{array}$} & Evet & 273 & 112.97 & 12.10 & \multirow{2}{*}{3.378} & \multirow{2}{*}{398} & \multirow{2}{*}{$0.001^{*}$} \\
\hline & Hayır & 127 & 108.55 & 12.40 & & & \\
\hline \multirow{2}{*}{$\begin{array}{l}\text { Okulda acil durum/afet } \\
\text { hazırlık planı hakkında } \\
\text { bilgi durumu }\end{array}$} & Evet & 139 & 113.86 & 12.94 & \multirow[b]{2}{*}{2.727} & \multirow[b]{2}{*}{398} & \multirow[b]{2}{*}{$0.007^{*}$} \\
\hline & Hayır & 261 & 110.35 & 11.88 & & & \\
\hline \multirow{2}{*}{$\begin{array}{l}\text { Acil durum/afetlere } \\
\text { hazırlık durumu }\end{array}$} & Evet & 126 & 114.57 & 13.99 & \multirow{2}{*}{3.089} & \multirow{2}{*}{202} & \multirow{2}{*}{$0.002^{*}$} \\
\hline & Hayır & 274 & 110.18 & 11.29 & & & \\
\hline \multirow{2}{*}{$\begin{array}{l}\text { Evde acil durum/afet } \\
\text { çantası olma durumu }\end{array}$} & Evet & 95 & 115.80 & 14.43 & \multirow{2}{*}{3.427} & \multirow{2}{*}{132} & \multirow{2}{*}{$0.001^{*}$} \\
\hline & Hayır & 305 & 110.25 & 11.34 & & & \\
\hline \multirow{2}{*}{$\begin{array}{l}\text { Okulda acil durum/afet } \\
\text { durumunda toplanma } \\
\text { yerini bilme durumu }\end{array}$} & Evet & 110 & 114.00 & 13.83 & \multirow{2}{*}{2.443} & \multirow{2}{*}{398} & \multirow{2}{*}{$0.015^{*}$} \\
\hline & Hayır & 290 & 110.64 & 11.64 & & & \\
\hline
\end{tabular}

${ }^{*}$ Değer istatistiksel olarak anlamlıdır (p<0.05). $n$ : sayı; $\bar{x}$ : ortalama; SS: standart sapma;t: $T$ testi, df: serbestlik derecesi; $p$ : anlamlı değer.

\section{TARTIŞMA}

Bu bölümde araștırmaya katılan öğrencilerin sosyodemografik özellikleri, acil durum/afet ile ilgili faktörlerin genel afete hazırlık inancı üzerine etkisi tartışılmıștır.

Bu araştırmaya katılan öğrencilerin genel afete hazırlık inanç ölçeği ve alt boyut puan ortalamaları incelendiğinde; öz yeterlilik alt boyutu puan ortalaması $30.55 \pm 4.57$, algılanan duyarlılık alt boyut puan ortalaması $21.51 \pm 2.90$, algllanan engeller alt boyut puan ortalaması $19.92 \pm 4.07$ ve genel afete hazırlık inanç ölçeği toplam puan ortalaması 111.57 \pm 12.36 olarak tespit edilmiştir. Inal et al. (2019) tarafından Yalova Üniversitesi akademik ve idari personeline yapılan bir araştırmada benzer şekilde öz yeterlilik alt boyut puan ortalaması $24.69 \pm 6.35$, algllanan duyarlılık alt boyutu puan ortalaması $26.57 \pm 4.04$, algılanan engeller alt boyut puan ortalaması $18.58 \pm 4.07$ ve genel afete hazırlık inanç ölçeği toplam puan ortalaması 107.03 \pm 14.02 olarak tespit edilmiştir (Inal et al., 2019). Genel afete hazırlık inanç ölçekleri toplam puan ortamlarının benzer ve ortalamanın üzerinde olduğunu göstermektedir. 
Literatürde yaş ile ilgili değişkenlikler farklılık gösterebilmektedir Araştırmamızda yaş grupları ile genel afete hazırlık inancı arasındaki ilişki değerlendirilmiş olup anlamlı bir fark olmadığı tespit edilmiştir. Amerika'da lisans ve yüksek lisans öğrencileri ile yapılan bir çalıșmada öğrencilerin yaşları ile doğal afetlere hazırlıklı olmaları arasında anlamlı bir ilişki olmadığı tespit edilmiştir (Tkachuck et al., 2018). Ulusal Medikal Kurtarma Ekipleri (UMKE) Derneği üyeleri üzerinde yapılan bir çalışmada 33-48 yaşları arasındaki katılımcıların 20-32 yaşları arasındaki katılımcılara oranla daha yüksek düzeyde afete hazırlıklı oldukları tespit edilmiştir (Ünal vd., 2017). Özellikle yaşla birlikte yaşanılan deneyimler afete hazırlık sürecini de artırabileceği düşünülmektedir. Örneklemimizde yaş dağılımları belirli bir yaș aralığındaki popülasyonu içerdiğinden anlamlı bir farklılık bulunamamıştır.

Araştırmamızda öğrencilerin öğrenim gördükleri bölüm ile genel afete hazırlık inancı arasındaki ilişki karşılaştırılmış olup anlamlı bir fark olmadığı belirlenmiştir. Çanakkale Sağlı Yüksekokulu Acil Yardım ve Afet Yönetimi, Ebelik ve Hemşirelik bölümü öğrencileriyle yapılan bir araştırmada; öğrencilerin öğrenim gördükleri bölüm ile deprem bilinci arasında anlamlı fark olduğu tespit edilmiştir. Deprem bilinci bilgi düzeyi değerlendirilerek "Çanakkale'nin kaçıncı deprem bölgesinde yer aldığını bilme durumları" sorulduğunda Acil Yardım ve Afet Yönetimi bölümü öğrencilerinin diğer bölümlere oranla bilgi düzeyinin daha yüksek olduğu tespit edilmiştir (Yükseler, 2019). Yapılan bir başka çalışmada Namık Kemal Üniversitesi Sağlık Yüksekokulu, Fen Edebiyat Fakültesi, İktisadi ve İdari Bilimler Fakültesi, Tıp Fakültesi, Teknik Bilimler Meslek Yüksekokulu, Sosyal Bilimler Meslek Yüksekokulu, Sağlık Hizmetleri Meslek Yüksekokulu ve Veterinerlik Fakültesi öğrencileri arasında afet bilincinin değerlendirilmesi ve farkındalık düzeyleri belirlenmiştir. Aynı çalışmada "herhangi bir afet anında bölgenizdeki toplanma alanlarını biliyor musunuz?" sorusuna evet cevabı veren en yüksek oran Tıp Fakültesi öğrencileri (\%71.4) iken, en düşük oran ise Sağllk Hizmetleri Meslek Yüksekokulu (\%34.4) öğrencileri tarafından verilmiştir (Dökmeci \& Merinç, 2018). Farkın araștırmamızın yapıldığı üniversite öğrencilerinin çoğunluğunu birinci sınıf öğrencilerinin oluşturması ve afet farkındalığıyla ilgili derslerin bölümlerin müfredatlarında yer almamasından kaynaklandığı düşünülmektedir.

Bireylerin geçmiş dönemlerdeki deneyimleri afete hazırlık sürecine katkı sağladı̆̆ düşünülmektedir. Araştırmamızda öğrencilere daha önce afet yaşama durumları sorulmuş olup afet yaşama durumu ile genel afete hazırlık inancı arasında anlamlı bir fark olmadığı tespit edilmiştir. Türkiye'de Van ve Bitlis illerinde yapılan bir araştırmaya göre; katılımcılardan doğrudan afete maruz kalan bireylerin afet sonrası hazırlık bilincinin doğrudan afete maruz kalmayanlara oranla daha yüksek olduğu belirlenmiştir (Uğur ve Işık, 2020). Araştırmamıza katılan bireylerin çoğunluğunun daha önceki yaşamlarında herhangi bir afet durumu yaşamamaları afete olan inançlarını da azalttığını göstermektedir.

Araştırmamızda cinsiyet ile genel afete hazırlık inancı arasındaki ilişki incelendiğinde anlamlı bir fark olduğu tespit edilmiştir. Farkın kaynağına bakıldığında kadınların genel afete hazırlık inancının erkeklere oranla daha yüksek olduğu belirlenmiştir. Yapılan bir başka araştırmada İran'da erkeklerin kadınlardan afete hazırlık davranış puanının daha yüksek olduğunu göstermektedir (Najafi et al., 2015). Ürdün'de yapılan bir başka çalışmada ise; erkek katılımcıların afet yönetimi için hazırlıklı olma durumları kadın katılımcılardan yüksek olarak belirlenmiștir (AlAli \& Ibaid, 2015). Farkın demografik özelliklerdeki ya da toplumsal yapıdaki değişkenliklerden kaynaklandığı düşünülmektedir.

Araştırmamızda daha önce acil durum/afet eğitimi alma durumu ile genel afete hazırlık inancı arasındaki ilişki incelendiğinde anlamlı bir fark tespit edilmiştir. Farkın kaynağı incelendiğinde acil durum/afet eğitimi alanların almayanlara oranla genel afete hazırlık inancının daha yüksek olduğu belirlenmiștir. Yapılan bir araștırmada, temel afet eğitimi alma durumu ile temel afet bilinci ile ilgili bilgi ve farkındalık düzeyleri arasında istatistiksel olarak anlamlı fark bulunmuştur. Temel 
Bir Vakıf Üniversitesi Sağlık Hizmetleri Meslek Yüksekokulunda Öğrenim Gören Öğrencilerin Genel Afete Hazırlıklı Olma İnanç Durumlarının Belirlenmesi

afet eğitimi alanların almayanlara oranla temel afet bilinci ile ilgili bilgi ve farkındalık düzeylerinin eğitim almayanlara oranla daha yüksek olduğu belirlenmiștir (İnal vd., 2012). Sağlık personelleri ile yapılan bir çalışmada afetle ilgili eğitim alanların eğitim almayanlara oranla afete hazırlık düzeyinin daha yüksek olduğu belirlenmiștir (Kocaman, 2019). Endonezya'da hemşireler ile yapılan bir çalışmada hemşirelerin acil durum ile ilgili aldıkları eğitim ile afet yönetimine hazırlıklı olma algısı arasında bilgi ve beceri açısından anlamlı fark bulunurken, değerlendirme açısından anlamlı bir ilişki tespit edilmemiştir (Martono et al., 2019). Araştırma sonucumuz literatürle benzerdir.

Araştırmamızda öğrencilere okullarında acil durum/afet hazırlık planı hakkındaki bilgi durumu sorularak genel afete hazırlık inancı arasındaki ilişki incelendiğinde anlamlı bir fark tespit edilmiştir. Bu fark öğrencilerin okullarında acil durum/afet hazırlık planı hakkında bilgisi olanların olmayanlara göre genel afete hazırlık inancının daha yüksek olduğunu göstermektedir. Yapılan bir araștırmada afet planı yapanların afet bilinci puan ortalaması afet planı yapmayanlara oranla daha yüksek bulunmuştur (İnal vd., 2012). Araştırmamız afet hazırlık planları hakkında bilgili olmayı önemli bulmaktadır.

Araştırmamızda öğrencilerin acil durum/afet hazırlık durumu ile genel afete hazırlık inancı arasındaki ilişki incelendiğinde anlamlı bir fark olduğu belirlenmiştir. Acil duruma/afete hazır olanların olmayanlara oranla genel afete hazırlık inancı daha yüksektir. Yapılan bir araștırmada acil durumlara/afetlere yeterince hazırlıklı olma durumu ile acil durumlara/afetlere hazırlık puanı arasında anlamlı bir farklılık saptanmıștır. Acil durum/afete hazırlıklı olanların olmayanlara oranla acil durum/afete hazırlık durumları daha yüksek olarak bulunmuștur (İnal, 2015). Türkiye'de yaplan bir araștırmada "Sizce Türk toplumu herhangi bir afete karşı ne kadar hazırlıklı?" sorusu yöneltildiğinde katılımcıların \%74,6'sı Türk toplumunun afetlere karşı hazırlıksız olduğunu belirtmiştir (AFAD, 2014). Tahran'da yapılan bir başka araştırmaya göre, katılımcıların \%80,8'inin depreme hazır olmadığını bildirdikleri belirlenmiștir (Najafi et al., 2018). Araştırmamız afete hazırlıklı olma ile afet hazırlık inancı arasındaki anlamlı ilişki olduğunu göstermektedir.

Araştırmamızda öğrencilerin evlerinde acil durum/afet çantası bulundurma durumu ile genel afete hazırlık inancı arasındaki ilişkiye bakılmış olup anlamlı bir fark tespit edilerek acil durum/afet çantası olanların olmayanlara oranla genel afete hazırlık inancının daha fazla olduğu tespit edilmiştir. Hong Kong'da yapılan bir araştırmaya göre katılımcıların \%51.6'sının ilk yardım çantasının olmadığını ve \%57.1'i Hong Kong topluluğunda afet bilincinin düşük olduğunu belirtmektedir (Chan et al., 2016). Araştırmamızda bireylerin afet çantasının olması afetlere hazırlılık durumunu artıracağını göstermektedir.

Araştırmamızda öğrencilerin okullarında acil durum/afet durumunda toplanma yerini bilme durumu ile genel afete hazırlık inancı arasındaki ilişki incelendiğinde anlamlı bir fark tespit edilmiştir. Öğrencilerin \%72.5'i okulda acil durum/afet durumunda toplanma yerini bilmemektedir. Bu farkın kaynağına bakıldığında acil durum/afet durumunda toplanma yerini bilenlerin genel afete hazırlık inancının bilmeyenlere oranla daha yüksek olduğu tespit edilmiștir. Üniversite öğrencileri üzerinde yapılan bir çalışmada "kendinizi olası afetlere karşı hazırlıklı olarak görüyor musunuz?" sorusu yöneltildiğinde \%78.3'ü hazırlıksız olduğunu bildirmiştir. Yine aynı çalışmada öğrencilerin \%91.6'sı okul afet planlarında toplanma bölgesinin neresi olduğunu bilmemektedir (Şahin vd., 2018). Araştırmamız literatürdeki çalışmaya benzerdir. 


\section{SONUÇ VE ÖNERÍLER}

Araştırmaya katılan öğrencilerin genel afete hazırlıklı olma inanç düzeyi puanının ortalamanın üzerinde olduğu ve kız öğrencilerin erkek öğrencilerden daha yüksek olduğu görülmüştür. Afetlerle ilgili eğitim alan öğrencilerin afete hazırlıklı olma inancının afet eğitimi almayanlara göre daha yüksek olduğu belirlenmiştir. Eğitim gördüğü üniversitenin afet planı hakkında bilgisi olanların ve toplanma noktasını bilenlerin afete hazırlıklı olma inancının bilmeyenlere oranla daha yüksek olduğu bulunmuştur. Üniversite öğrencilerinin afetlere yönelik hazırlıklı olanların ve evinde acil durum çantası olanların afete hazırlıklı olma inancının daha yüksek olduğu görülmektedir.

Elde edilen sonuçlar ıșığında;

- Üniversitelerde bulunan öğrencilerin ders müfredatlarına afet farkındalığıyla ilgili derslerin eklenmesi,

- Üniversite öğrencilerine afete hazırlık kapsamında tatbikatlar düzenlenmesi,

- Afetlere hazırlık kapsamında AFAD’la iletişime geçilerek simalatörler kullanılması,

- Üniversitelerdeki yöneticilerin başta toplanma noktası olmak üzere afetlerle ilgili birçok konuda öğrencilerin dikkatini çekecek, farkındalıklarını arttıracak görsel materyallerin hazırlanması ve bu materyallerin öğrencilerin görebilecekleri noktalara konulması,

- Üniversitelerde afet topluluklarının kurularak üniversite içerisinde faaliyetlerini arttırmasının sağlanması ve her evde afet çantası hazırlanması konusunda faaliyetlerin düzenlenmesi önerilmektedir.

\section{TEŞEKKÜR}

Başkent Üniversitesi Sağlık Hizmetleri Meslek Yüksekokulu öğrencilerine teşekkür ederiz.

\section{KAYNAKLAR}

AFAD (2014). Türkiye, afet farkındalığı ve afetlere hazırlık araştırması, Başbakanlık Afet ve Acil Durum Yönetimi Başkanlığı. https://www.afad.gov.tr/kurumlar/afad.gov.tr/3923/xfiles/turkiye-afet-farkindaligive-afetlere-hazirlik-arastirmasi_-2014-edited.pdf (Son erişim tarihi: 12.12.2019)

AFAD (2018). Türkiye'de afet yönetimi ve doğa kaynaklı afet istatistikleri, Afet ve Acil Durum Yönetimi Başkanlığı. https://www.afad.gov.tr/kurumlar/afad.gov.tr/35429/xfiles/Turkiye_de_Afetler.pdf (Son erişim tarihi: 16.12 .2019 )

AFAD (2019a). AFAD hakkında. 5 Eylül 2019'da https://www.afad.gov.tr/tr/2211/AFAD-Hakkinda adresinden alındı. (Son erişim tarihi: 18.12.2019)

AFAD (2019b). Afete hazır okul. 5 Eylül 2019'da https://www.afad.gov.tr/tr/23188/Afete-Hazir-Okul adresinden alındı (Son erişim tarihi: 12.12.2019)

AFAD (2019c). Açılamalı afet yönetimi terimleri.1 Eylül 2019'da https://www.afad.gov.tr/tr/23792/Aciklamali-Afet-Yonetimi-Terimleri-Sozlugu?kelime=afet adresinden alındı (Son erişim tarihi: 05.12.2019)

Al-Ali, N. M., \& Ibaid, A. H. (2015). Health-care providers' perception of knowledge, skills and preparedness for disaster management in primary health-care centres in Jordan. East Mediterranean Health Journal, 21(10), 713-721. https://doi.org/10.26719/2015.21.10.713 
Bir Vakıf Üniversitesi Sağlık Hizmetleri Meslek Yüksekokulunda Öğrenim Gören Öğrencilerin Genel Afete Hazırlıklı Olma İnanç Durumlarının Belirlenmesi

Chan, E. Y., Yue, J., Lee, P., \& Wang, S. S. (2016). Socio-demographic predictors for urban community disaster health risk perception and household based preparedness in a Chinese urban city. PLoS Current, 8. https://doi.org/10.1371/currents.dis.287fb7fee6f9f4521af441a236c2d519

Dougles, P. (2018). Disaster risk reduction: Psychological perspectives on preparedness. The Australian Psychological Societ,71:327-341 https://doi.org/10.1111/ajpy.12237

Dökmeci, A. H., \& Merinç, F. (2018). Namık Kemal Üniversitesi öğrencilerinin temel afet farkındalığının değerlendirilmesi. Afet ve Risk Dergisi, 1(2), 106-113. https://doi.org/10.35341/afet.454340

Ersoy, Ş., Nurlu, M., Gökçe, O., \& Özmen, B. (2017). 2016 yılında dünyada ve Türkiye'de meydana gelen doğa kaynaklı afet kayıplarının istatistiksel değerlendirmesi. Mavi Gezegen Dergisi, 22, 13-27.

Ejeta, L.T, Ardalan, A., \& Paton, D. (2015). Application of behavioral theories to disaster and emergency health preparedness. A systematic review. PLOS Currents Disasters, 7, 2015

Inal, E., Altintas, K. H., \& Dogan, N. (2018). The development of a general disaster preparedness belief scale using the Health Belief Model as a theoretical framework. International Journal of Assessment Tools in Education, 5(1), 146-158. https://doi.org/10.21449/ijate.366825

Inal, E., Altintas, K. H., \& Dogan, N. (2019). General disaster preparedness belief and related sociodemographic characteristics: The example of Yalova University, Turkey. Turkish Journal of Public Health, 17(1), 1-15. https://doi.org/10.20518/tjph.381667

İnal, E., Kocagöz, S., \& Turan, M. (2012). Temel afet bilinç ve hazırlık düzeyinin saptanmasına yönelik bir araştırma. Türkiye Acil Tıp Dergisi, 12(1), 15-19. https://doi.org/10.5505/1304.7361.2012.05658

İnal, E. (2015). Acil Durumlara/Afetlere Bireysel Hazırlığı Değerlendirmek için Sağlık İnanç Modeli'ne Dayalı Ölçek Geliştirme (Yayınlanmamış doktora tezi), Hacettepe Üniversitesi, Halk Sağlığı Enstitüsü, Ankara.

Kadıŏlu, M. (2008). Modern, Bütünleşik Afet Yönetiminin Temel İlkeleri. M. Kadıŏlu, \& E. Özdamar (Editörler), Afet Zararlarını Azaltmanın Temel İlkeleri içinde (ss. 1-34). JICA Türkiye Ofisi Yayınları.

Kocaman, Y. (2019). 112'de Çalışan Personelin Afete Hazırlık Düzeyinin İncelenmesi: Gümüşhane İli Örneği, Gümüşhane Üniversitesi, Sosyal Bilimler Enstitüsü, Yüksek Lisans Tezi, Gümüşhane.

Macit, İ. (2019). Bütünleşik afet yönetiminde Sendai Çerçeve Eylem Planı'nın beklenen etkisi. Doğal Afetler ve Çevre Dergisi, 5(1), 175-186. https://doi.org/10.21324/dacd.421564

Martono, M., Satino, S., Nursalam, N., Efendi, F., \& Bushy, A. (2019). Indonesian nurses'perception of disaster management preparedness. Chinese Journal of Traumatology, 22(1), 41-46. https://doi.org/10.1016/i.cjtee.2018.09.002

Najafi, M., Ardalan, A., Akbarisari, A., Noorbala, A. A., \& Jabbari, H. (2015). Demographic determinants of disaster preparedness behaviors amongst Tehran Inhabitants, Iran. PLoS Currents, 11(7). https://doi.org/10.1371/currents.dis.976b0ab9c9d9941cbbae3775a6c5fbe6

Najafi, M., Khankeh, H. R., Elmi, H., \& Pourvakhshoori, N. (2018). Behavioral, normative and control beliefs about eartquake preparedness: A deductive content analysis study. PLoS Currents, 10. https://doi.org/10.1371/currents.dis.20fbad29d53fb164ac2699dc2736d804

Painter, J.E., Borba, C.P., Hynes, M., Mays, D., \& Glanz, K. (2008). The use of theory in health behavior research from 2000 to 2005: a systematic review. Annals of Behavioral Medicine, 35 (3), 358-362.

Sari, A. L. (2019). School in earthquake threat: School based disaster preparedness model in Indonesia. Preprints. https://doi.org/10.20944/preprints201902.0253.v1 
Şahin, Ş, \& Üçgül, İ. (2019). Türkiye'de afet yönetimi ve iş sağlığı güvenliği. Afet ve Risk Dergisi, 2(1), 43-63. https://doi.org/10.35341/afet.498594

Şahin, Y., Lamba, M., \& Öztop, S. (2018). Üniversite öğrencilerinin afet bilinci ve afete hazırlık düzeylerinin belirlenmesi. Medeniyet Araştırmaları Dergisi, 3(6), 149-159.

Tkachuck, M. A., Schulenberg, S. E., \& Lair, E. C. (2018). Natural disaster preparedness in college students: Implications for institutions of higher learning. Journal of American College Health, 66(4), 269-279. https://doi.org/10.1080/07448481.2018.1431897

Uğur, A., Işıı M. (2020). Türkiye'nin Afetlere Hazırlık Politikalarının Toplum Algısı Üzerinden Karşılaştırmalı Analizi: Van-Bitlis Örneği. Doğal Afetler ve Çevre Dergisi, 6(1): 98-118, DOI: 10.21324/dacd.542528

UNISDR (2016). Report of the open-ended intergovernmental expert working group on indicators and terminology relating to disaster risk reduction. Geneva, Switzerland: United Nations Office for Disaster Risk Recudtion. Retrived from https://www.preventionweb.net/files/50683_oiewgreportenglish.pdf (Son erişim tarihi: 04.04.2020)

URL-1, 2017 yılı iklim değerlendirmesi, Meteoroloji Genel Müdürlüğü.

https://www.mgm.gov.tr/FILES/iklim/yillikiklim/2017-iklim-raporu.pdf (Son erişim tarihi: 04.04.2020)

URL-2, 2018 yılı iklim değerlendirmesi, Meteoroloji Genel Müdürlüğü. https://www.mgm.gov.tr/FILES/genel/kitaplar/2018MeteorolojikAfetlerDegerlendirmesi.pdf (Son erişim tarihi: 04.04.2020)

Ünal, Y., Işılk, E., Şahin, S., \& Yeşil, S. T. (2017). Sağlık afet çalışanlarının depremlere ilişkin bireysel hazırlık düzeylerinin değerlendirilmesi: Ulusal Medikal Kurtarma Ekipleri (UMKE) Derneği örneği. DEÜ Tıp Fakültesi Dergisi, 31(2), 71-80.

Varol, N., \& Kırıkkaya, E. B. (2017). Afetler karşısında toplum dirençliliği. Dirençlilik Dergisi, 1(1), 1-9. https://doi.org/10.32569/resilience.344784

Yıldırım, A. (2004). Acil durumda basın ve halkla ilişkiler. İçişleri Bakanlığı Eğitim Dairesi Başkanlığı Afet Yönetimi 55. Dönem Mülki İdare Amirleri Semineri, Ders Notu, Ankara.

Yükseler, M. (2019). Çanakkale Onsekiz Mart Üniversitesi Sağlık Yüksekokulu 1. Sınıf Öğrencilerinin Deprem Bilinci Bilgi Düzeyleri (Yayınlanmamış yüksek lisans tezi), Çanakkale Onsekiz Mart Üniversitesi, Eğitim Bilimleri Enstitüsü, Çanakkale. 